\title{
Article \\ Dietary Curcumin Alleviated Acute Ileum Damage of Ducks (Anas platyrhynchos) Induced by AFB1 through Regulating Nrf2-ARE and NF-KB Signaling Pathways
}

\author{
Sanjun Jin, Hao Yang, Yihan Jiao, Qian Pang, Yingjie Wang, Min Wang, Anshan Shan and Xingjun Feng * \\ Laboratory of Molecular Nutrition, Institute of Animal Nutrition, Northeast Agricultural University, \\ Changjiang Street 600\#, Xiangfang District, Harbin 150030, China; Sanjunjin@163.com (S.J.); \\ yanghao951209@163.com (H.Y.); yihanjiao11@163.com (Y.J.); pangqian1210@163.com (Q.P.); \\ 18846091206@163.com (Y.W.); 17854221802@163.com (M.W.); asshan@neau.edu.cn (A.S.) \\ * Correspondence: fengxingjun@neau.edu.cn; Tel.: +86-451-55191395
}

Citation: Jin, S.; Yang, H.; Jiao, Y.; Pang, Q.; Wang, Y.; Wang, M.; Shan, A.; Feng, X. Dietary Curcumin Alleviated Acute Ileum Damage of Ducks (Anas platyrhynchos) Induced by AFB1 through Regulating Nrf2-ARE and NF- $\kappa$ B Signaling Pathways. Foods 2021, 10, 1370. https://doi.org/10.3390/ foods10061370

Academic Editors: Zheng Ruan,

Ming Jian and Xinli Li

Received: 9 May 2021

Accepted: 10 June 2021

Published: 14 June 2021

Publisher's Note: MDPI stays neutral with regard to jurisdictional claims in published maps and institutional affiliations.

Copyright: (c) 2021 by the authors. Licensee MDPI, Basel, Switzerland. This article is an open access article distributed under the terms and conditions of the Creative Commons Attribution (CC BY) license (https:// creativecommons.org/licenses/by/ $4.0 /)$.

\begin{abstract}
Aflatoxin B1 (AFB1) is a stable toxic metabolite threatening health of human and animal and widely contaminated animal feed and human food. This present study aimed to investigate the effects of dietary curcumin on ileum injury in ducks induced by AFB1 administration and explore its underlying mechanisms. Ducks $(N=450$, one-day-old male) with a similar weight were randomly assigned to 3 groups, containing the control group, AFB1 group ( $60 \mu \mathrm{g}$ AFB1 kg $\mathrm{kg}^{-1}$ body weight) and curcumin (500 mg curcumin $\mathrm{kg}^{-1}$ diet) + AFB1 group. AFB1 administration markedly increased the ileum damage, AFB1-DNA adducts in the plasma and oxidation stress and inflammation. Adding curcumin into diet protected the ileum against morphology damage induced by AFB1 administration, decreased AFB1-DNA adducts in the plasma and eliminated oxidation stress and inflammation in the ileum of ducks. Anti-oxidation and anti-inflammatory effects of curcumin could protect the ileum against acute damage via activating Nrf2-ARE signaling pathway and inhibiting NF- $\mathrm{kB}$ signaling pathway. Conclusively, curcumin was a dietary anti-oxidation and anti-inflammation agent via activating Nrf2-ARE signaling pathway and inhibiting NF- $\mathrm{kB}$ signaling pathway to protect ileum against acute damage induced by AFB1 administration.
\end{abstract}

Keywords: curcumin; acute ileum; AFB1-DNA adducts; Nrf2-ARE; ducks

\section{Introduction}

Meat is an important source of high-quality protein for human nutrition. Duck meat is abundantly consumed worldwide, especially in Asia because of its desirable nutritional characteristics [1]. Therefore, the breeding of ducks has attracted people's attention. For ducks, there are various disadvantages in the breeding process, such as AFB1 that threaten the health of ducks. Aflatoxin B1 (AFB1) is one of table toxic metabolites produced by Aspergillus species. AFB1 is recognized as the most toxic among aflatoxin (AF) groups, along with an assortment of toxic effects to threat the health of human and animals [2]. For people or animals, food or feed is a common and important way to exposure to AFB1, but inhalation and direct contact with skin or mucosa contact are also counted and not ignored [3]. Previous studies have proved that AFB1 exerts a potent toxicity that is very complex and strong, resulting in growth retardation, biological malformations, liver toxicity, digestive tract disorders and even cancer [4,5]. AFB1 obtained from food or mucosa contact had negative effects on respiratory systems, digestive system and tissues and growth performance [3,6,7]. Tissue and organ damages induced by AFB1 administration related to oxidation stress and inflammation. AFB1 administration marked increased AFB1-DNA adducts content in injured organ [8]. The absorption and conversion of nutrients and toxins were occurred in the stomach and small intestine, so the small intestine mucosal immune system is the first line to protect bodies against injury [9]. The 
functionality and morphology of the health gastrointestinal tract could be destroyed by unfavorable factors such as toxicants, bacteria and viruses $[10,11]$. AFB1 induced the destruction of the intestinal structure, manifested by shedding of epithelial cells in jejunal villus and lymphocytic cell infiltration in the intestine of chicken $[12,13]$. The variation of functionality and morphology may be attributed to the process of toxin metabolism that is often accompanied by oxidative stress and inflammation. It is an urgent matter to find an antidote to reduce and minimize the threat of AFB1 for people and animals. Consequently, AFB1 is one of the foremost concerns in poultry industry due to its potent toxicity.

Curcumin is a kind of polyphenol component occurring in turmeric rhizomes (Curcuma Longa Linn) as a functional feed additive used in livestock feed [14], and widely used as a green and natural spice, colorant, preservative and flavoring in the food industry. Plant extracts such as curcumin containing polyphenols improved the body's immunity [15]. Curcumin plays a key role against oxidative stress mediated pathological conditions and it has anti-inflammatory activities when used as a therapy for treatment and prevention of chronic diseases $[16,17]$. The clinical trials indicated that curcumin have not severe toxic or side effect, and with anti-carcinogenic and anti-toxicogenic properties, which led to curcumin as an attractive chemopreventive agent against AFB1-induced tissues damage [18-20]. Literatures demonstrated that curcumin has ability to anti-inflammation, anti-apoptosis and antioxidation by activating the Nrf2/HO-1 pathway, upregulated antioxidation capacity to eliminate inflammation and oxidative stress in the body and eliminate AFB1-induced oxidative stress [21-25]. Curcumin suppressed oxidation stress and inflammasome formation by activating Nrf2-ARE and inhibiting NF- $\mathrm{KB}$ signaling pathway in remnant kidney [26], demonstrating anti-oxidation and anti-inflammatory property. In addition, dietary curcumin significantly improved the antioxidant capacity in broilers [27] and ducks [28]. There was no attempt to correlate the role of curcumin in Nrf2-ARE and NF- $\mathrm{kB}$ signaling pathway and in animal model of acute AFB1 administration. This study shed light on this issue and provided a theoretical basis for curcumin as a feed additive to protect duck's health against AFB1 administration and reduce economic losses of feed and breeding industries caused by AFB1 pollution.

\section{Materials and Methods}

\subsection{Chemicals}

Curcumin was purchased from Nanjing Nutri-herb Biotech Co., Ltd. (Nanjing, Jiangsu, China, CAS: $458-37-7)$, its purity was more than $98 \%$ by HPLC analysis. AFB1 (purity $\geq 98 \%$, CAS NO. 1162-65-8) was purchased from Shanghai Yuan ye Bio-Technology Co., Ltd. (Shanghai, China). Antibodies used in this study were purchased from Beyotime Biotechnology, Shanghai, China, including GAPDH (Catalog number: AG019), Nrf2 (Catalog number: AF7623), Phospho-NF-kB p65 (Ser276) (Catalog number: AF5875), HRPlabeled Goat Anti-Rabbit IgG (H + L) (Catalog number: A0208) and HRP-labeled Goat Anti-Mouse IgG (H + L) (Catalog number: A0216).

\subsection{Ducks and Husbandry}

The experimental protocol was conducted in accordance with the practices outlined in the Guide for the Care and Use of Agricultural Animals in Agriculture Research and Teaching of Northeast Agricultural University (Protocol number: NEAU-[2011]-9).

Ducks ( $n=450$, one-day-male Anas platyrhynchos, $33.8 \pm 0.2 \mathrm{~g}$ ) with no significant different weight were purchased from a commercial hatchery and randomly assigned to 3 groups (Table 1), with 10 replicate pens (cages) per group and 15 ducks per pen for a 70-day feeding trial. The basal diets were formulated according to National Research Council (1994). Ducks in the $\mathrm{T}_{0}$ and $\mathrm{T}_{0}+\mathrm{AFB} 1$ group were fed a corn-soybean basal diet (Table 2), ducks in the $T_{500}+$ AFB1 group were fed the basal diet supplemented with $500 \mathrm{mg}$ of curcumin $\mathrm{kg}^{-1}$ of diet $\left(T_{500}\right)$ a 70 -day trial. On the 70 days, ducks with similar body weight in the $\mathrm{T}_{0}+\mathrm{AFB} 1$ and $\mathrm{T}_{500}+\mathrm{AFB} 1$ groups were fed $60 \mu \mathrm{g}$ of AFB1 $\mathrm{kg}^{-1}$ of body weight, and ducks in the $T_{0}$ group were fed the equal volume of PBS solution. Ducks were fed 
in Acheng Experimental Base of Northeast Agricultural University and provided with ad libitum access to water and powdered diets. Fifteen ducks with similar body weight $(1.4 \pm 0.3 \mathrm{~kg})$ from each group were selected and fasted for $12 \mathrm{~h}$, then fed PBS solution to ducks in $T_{0}$ group and $60 \mu \mathrm{g}$ of AFB1 $\mathrm{kg}^{-1}$ of body weight to ducks in $\mathrm{T}_{0}+\mathrm{AFB} 1$ and $\mathrm{T}_{500}+\mathrm{AFB} 1$ groups at same time. After $12 \mathrm{~h}$, the fifteen ducks in each group were to obtain duck samples.

Table 1. Experiment design.

\begin{tabular}{ccc}
\hline Groups & Basal Diet & Curcumin (mg Curcumin/kg Basal Diet) \\
\hline $\mathrm{T}_{0}$ & corn-soybean & 0 \\
$\mathrm{~T}_{0}$ & corn-soybean & $0+\mathrm{AFB} 1$ \\
$\mathrm{~T}_{500}$ & corn-soybean & $500+$ AFB1 \\
\hline
\end{tabular}

$\mathrm{T}_{0}$ : ducks fed basal diet for 70 days then fed PBS water on 70 day; $\mathrm{T}_{0}+\mathrm{AFB1}$ : ducks fed basal diet for 70 days then fed $60 \mu \mathrm{g}$ of AFB1 $/ \mathrm{kg}$ of duck body weight on 70 day; $\mathrm{T}_{500}+\mathrm{AFB} 1$ : ducks fed $500 \mathrm{mg}$ of curcumin $\mathrm{kg}^{-1}$ of basal diet for 70 days then fed $60 \mu \mathrm{g}$ of AFB1 kg-1 of duck body weight on 70 day.

Table 2. Ingredient composition and nutrient content of the basal diet (\%, as-fed basis).

\begin{tabular}{|c|c|c|c|}
\hline Items & 1-4 Weeks ${ }^{1}$ & 5-8 Weeks ${ }^{2}$ & 9-10 Weeks ${ }^{3}$ \\
\hline \multicolumn{4}{|l|}{ Ingredient } \\
\hline Corn (7.9) & 61.70 & 68.94 & 75.80 \\
\hline Soybean meal (45) & 26.09 & 26.80 & 20.10 \\
\hline Corn protein flour (55) & 7.90 & - & - \\
\hline Dicalcium phosphate & 1.40 & 1.40 & 1.40 \\
\hline Limestone & 1.08 & 1.06 & 1.06 \\
\hline Salt & 0.38 & 0.38 & 0.38 \\
\hline DL-Methionine & 0.15 & 0.22 & 0.16 \\
\hline L-Lysine & 0.20 & 0.10 & 0.00 \\
\hline choline chloride $(50 \%)$ & 0.10 & 0.10 & 0.10 \\
\hline Premix & 1.00 & 1.00 & 1.00 \\
\hline Total & 100 & 100 & 100 \\
\hline \multicolumn{4}{|l|}{ Nutritional level } \\
\hline \multicolumn{4}{|l|}{ Calculated nutrient 4} \\
\hline Metabolizable energy (MJ/kg) & 12.14 & 11.98 & 12.21 \\
\hline $\mathrm{CP}(\%)$ & 20.67 & 17.51 & 15.03 \\
\hline Calcium $(\%)$ & 0.90 & 0.90 & 0.88 \\
\hline Total phosphorus (\%) & 0.68 & 0.67 & 0.65 \\
\hline Non-phytate phosphorus (\%) & 0.44 & 0.44 & 0.44 \\
\hline Lysine $(\%)$ & 1.07 & 0.95 & 0.71 \\
\hline Methionine $(\%)$ & 0.48 & 0.48 & 0.39 \\
\hline Methionine + cystine (\%) & 0.81 & 0.75 & 0.63 \\
\hline Threonine $(\%)$ & 0.75 & 0.66 & 0.56 \\
\hline Tryptophane (\%) & 0.21 & 0.19 & 0.16 \\
\hline
\end{tabular}

${ }^{1}$ The premix provided per kilogram diet: vitamin A $4000 \mathrm{IU}$, vitamin D3 $2000 \mathrm{IU}$, vitamin E $20 \mathrm{mg}$, vitamin K3 $2.0 \mathrm{mg}$, vitamin B1 $2.0 \mathrm{mg}$, vitamin B2 $12 \mathrm{mg}$, vitamin B6 $3.0 \mathrm{mg}$, vitamin B12 $0.02 \mathrm{mg}$, nicotinic acid $50 \mathrm{mg}$, D-pantothenic acid $10 \mathrm{mg}$, folic acid $1 \mathrm{mg}$, biotin $0.2 \mathrm{mg}$, Cu $8 \mathrm{mg}$, Fe $60 \mathrm{mg}$, Mn $100 \mathrm{mg}$, Zn $60 \mathrm{mg}$, Se $0.2 \mathrm{mg}$, I $0.4 \mathrm{mg} .{ }^{2}$ The premix provided per kilogram diet: vitamin A $3000 \mathrm{IU}$, vitamin D3 $2000 \mathrm{IU}$, vitamin E $10 \mathrm{mg}$, vitamin K3 $2.0 \mathrm{mg}$, vitamin B1 $1.5 \mathrm{mg}$, vitamin B2 $8 \mathrm{mg}$, nicotinic acid $30 \mathrm{mg}$, D-pantothenic acid $10 \mathrm{mg}$, vitamin B6 $3.0 \mathrm{mg}$, vitamin B12 $0.02 \mathrm{mg}$, biotin $0.1 \mathrm{mg}$, folic acid $1 \mathrm{mg}, \mathrm{Cu} 8 \mathrm{mg}$, Fe $60 \mathrm{mg}$, Mn $80 \mathrm{mg}$, Zn $40 \mathrm{mg}$, Se $0.2 \mathrm{mg}$, I 0.4 mg. ${ }^{3}$ The premix provided per kilogram diet: vitamin A $2500 \mathrm{IU}$, vitamin D3 $1000 \mathrm{IU}$, vitamin E $10 \mathrm{mg}$, vitamin K3 $2.0 \mathrm{mg}$, vitamin B1 $1.5 \mathrm{mg}$, vitamin B2 $8 \mathrm{mg}$, nicotinic acid $30 \mathrm{mg}$, D-pantothenic acid $10 \mathrm{mg}$, vitamin B6 $3.0 \mathrm{mg}$, vitamin B12 $0.02 \mathrm{mg}$, biotin $0.1 \mathrm{mg}$, folic acid $1 \mathrm{mg}$, Cu $8 \mathrm{mg}$, Fe $60 \mathrm{mg}$, Mn 80 mg, Zn 40 mg, Se $0.2 \mathrm{mg}$, I $0.3 \mathrm{mg} .{ }^{4}$ Values were calculated based on the data provided by Feed Database in China (2004).

\subsection{Sample Collection}

Blood samples $(10 \mathrm{~mL})$ were obtained using heparin tubes from veins of duck wings and centrifuged at $1000 \times g$ for $15 \mathrm{~min}$ at $4{ }^{\circ} \mathrm{C}$. The obtained plasma was immediately separated and stored at $-80^{\circ} \mathrm{C}$ for analyzing. Ducks were anesthetized by inhaling ether and killed to obtain ileum. The ileum was washed 3 times in PBS, immediately and individually stored in a liquid nitrogen tank then at $-80^{\circ} \mathrm{C}$ for qRT-PCR and antioxidant capacity 
analysis. Then, about $0.125 \mathrm{~cm}^{3}$ ileum was obtained and put into $4 \%$ paraformaldehyde solution for tissues section and about $1 \mathrm{~mm}^{3}$ ileum were put into electron microscopic solution at $4{ }^{\circ} \mathrm{C}$ for later ultrastructural observation.

\subsection{Assay of Antioxidant Levels in the Plasma}

Plasma levels of total superoxide dismutase (T-SOD), glutathione peroxidase (GSH$\mathrm{Px}$ ), Glutathione S-transferase (GSH-ST) and malondialdehyde (MDA) were measured by assay kits (Nanjing Jiancheng Bioengineering Institute, Nanjing, China), respectively, with UV-VIS Spectrophotometer (UV1100, MAPADA, Shanghai, China).

\subsection{Assay of AFB1-DNA Adducts Levels in the Plasma}

The generation of AFB1-DNA adducts in the plasma were determined using ELISA kits according to the kit's specifications (Nanjing Jiancheng Bioengineering Institute, Nanjing, China).

\subsection{Assay of Antioxidant Ability in Ileum}

Ileum $(100.00 \mathrm{mg})$ was devolved and mixed in $0.9 \mathrm{~mL}$ stroke-physiological saline solution $\left(4{ }^{\circ} \mathrm{C}, 0.9 \% \mathrm{NaCl}, \mathrm{pH}=7.2-7.4\right)$ to obtain $10 \%$ ileum/SPSS homogenate. The activity or content of total superoxide dismutase (T-SOD U/mg Protein), reductive Glutathione (GSH-PX $\mu \mathrm{mol} / \mathrm{mg}$ Protein), Glutathione S-transferase (GSH-ST U/mg Protein) and Malondialdehyde (MDA nmol/mg Protein) in ileum were assessed using assay kits (Nanjing Jiancheng Bioengineering Institute, Nanjing, China), respectively, with a UV-VIS spectrophotometer (UV1100, MAPADA, Shanghai, China).

\subsection{RNA Isolation and Real-Time Quantitative Polymerase Chain Reaction (qRT-PCR)}

Total RNA of the duck ileum (100.00 mg) was isolated using a reagent kit (TaKaRa, Japan) according to the protocol recommended by manufacturers. The concentration and purity of total RNA were detected at A260/A280 ratio with a spectrophotometer (IMPLEN, Germany). $1 \mu \mathrm{g}$ total RNA in each sample was converted into the cDNA with a Prime Script ${ }^{\mathrm{TM}}$ RT reagent kit with gDNA Eraser (TaKaRa, Dalian, China) according to the protocol recommended by manufacturers. The obtained cDNA from each duck ileum was used as a template for a TB Green ${ }^{\mathrm{TM}}$ Premix Ex Taq ${ }^{\mathrm{TM}}$ (TaKaRa, Dalian, China) RT-PCR (qRT-PCR) kit. The gene accession number of ducks was obtained from NCBI and the duck gene primers were synthesized by Sangon Biotech Co., Ltd. (Shanghai, China) (Table 3). The relevant gene expression in the duck ileum was determined by the Quanta gene Q225 thermal cycler apparatus. The qRT-PCR was run in Monad Selected Real-Time PCR System (ABI 7500 real-time PCR instrument (USA)) flowing to the condition: one cycle at $95^{\circ} \mathrm{C}$ for $30 \mathrm{~s}, 40$ cycles at $95{ }^{\circ} \mathrm{C}$ for $5 \mathrm{~s}$ and at $60{ }^{\circ} \mathrm{C}$ for $30 \mathrm{~s}$. The relative gene expression ratio of detection mRNA was detected using the $2^{-\Delta \Delta \mathrm{Ct}}$ method and normalized to $\beta$-actin expression.

\subsection{Western Blotting}

The duck ileum was pulverized and lysed in RIPA buffer containing $1 \mathrm{mmol} / \mathrm{L}$ PMSF (Beyotime, Shanghai, China) in the ice. Total protein concentration of the ileum was determined by a bicinchoninic acid (BCA) assay kit (Nanjing Jiancheng Bioengineering Institute, Nanjing, China). $12 \%$ and 10\% SDS-polyacrylamide gel for electrophoresis were used to obtain target proteins with different molecular weight. Then, target proteins were transferred to a polyvinylidene-difluoride (PVDF) membrane (Beyotime, Shanghai, China) for blots with a transblotting apparatus. The PVDF membrane was washed 3 times for 10 min each time in $1 \times$ PBST and then blocked $2 \mathrm{~h}$ in $5 \%$ skim milk. The PVDF membrane was washed 3 times again, and incubated with GAPDH, Nrf2 and P-P65 (Beyotime Biotechnology, Shanghai, China) primary antibodies for $8-12 \mathrm{~h}$ at $4{ }^{\circ} \mathrm{C}$, respectively. Next day, the PVDF membrane was washed 3 times again, and incubated with corresponding horseradish peroxidase labeled antibody at $37^{\circ} \mathrm{C}$ for $1 \mathrm{~h}$, then washed 3 times again. Target 
protein bands were detected and visualized under the action of the enhanced fluorescence detection kit BeyoECL Star (Beyotime Biotechnology, Shanghai, China). Images of blots were recorded and analyzed by the Essential V6 imaging platform (UVITEC, Cambridge, England). GAPDH protein served as an internal control protein. All the results of experiment were repeated in triplicate. The relative expressions of target proteins were expressed as the ratio of band intensities of proteins to GAPDH.

Table 3. Sequences, product sizes and TM values of primers for target genes.

\begin{tabular}{|c|c|c|c|c|}
\hline Transcripts & Accession Number & & Gene Sequence $\left(5^{\prime}-3^{\prime}\right)$ & Product Length $(b p)$ \\
\hline \multirow{2}{*}{ Keap1 } & \multirow{2}{*}{ MF774811.1 } & Forward & TCAСССТССАТАААСССАСССАAG & 102 \\
\hline & & Reverse & AGTAGCCCAAGGACTGCCGATAG & 102 \\
\hline \multirow{2}{*}{ Nrf2 } & \multirow{2}{*}{ NM_001310777.1 } & Forward & GTTGAATCATCTGCCTGTGG & 171 \\
\hline & & Reverse & TAAGCTAGGTGGTCGAGTGC & 172 \\
\hline \multirow{2}{*}{ HO-1 } & \multirow{2}{*}{ KU048806.1 } & Forward & AAGAGCCAGGAGAACGGTCACC & 139 \\
\hline & & Reverse & TGCCCACCAGGTCTGTCTGAC & 139 \\
\hline \multirow{2}{*}{ SOD1 } & \multirow{2}{*}{ XM_013097859.1 } & Forward & CCTGTGGTGTCATCGGAATA & 116 \\
\hline & & Reverse & TTGAACGAGGAAGAGCAAGTA & 127 \\
\hline \multirow{2}{*}{ GCLC } & \multirow{2}{*}{ XM_027455104.1 } & Forward & TTCAGGTGACATTCCAGGCTTGC & 108 \\
\hline & & Reverse & AGAACGGAGATGCAGCACTCAATG & 108 \\
\hline \multirow[b]{2}{*}{ GCLM } & \multirow{2}{*}{ XM_027462629.1 } & Forward & TGTTGTGTGATGCCACCTGATCTC & 150 \\
\hline & & Reverse & CCATTCGTGTGCTTTGACGTTCTG & 150 \\
\hline \multirow{2}{*}{ CAT } & \multirow{2}{*}{ KU048802.1 } & Forward & TGTGCGTGACTGACAACCAAGG & 96 \\
\hline & & Reverse & ACATGCGGCTCTCCTTCACAAC & 96 \\
\hline \multirow{2}{*}{ NQO-1 } & \multirow{2}{*}{ XM_027466610.1 } & Forward & CGTCGCCGAGCAGAAGAAGATC & 195 \\
\hline & & Reverse & CTGGTGGTGAACGACAGCATGG & 195 \\
\hline \multirow{2}{*}{ GST } & \multirow{2}{*}{ LOC101797566 } & Forward & ACAAGGCTGCAACCAGATACTTCC & 178 \\
\hline & & Reverse & ACTGCACATCTGCTCTGCTAAGC & 178 \\
\hline \multirow{2}{*}{ GPX } & \multirow{2}{*}{ XM_027459004.1 } & Forward & GAACGGCACCAACGAGGAGATC & 99 \\
\hline & & Reverse & TTCACCTGGCACTTCTGGAACAG & 99 \\
\hline \multirow{2}{*}{ NLRP3 } & \multirow{2}{*}{ МH373356.1 } & Forward & CGCTGAACGAGGACGCACTG & 124 \\
\hline & & Reverse & TGGAAGGGTAGTCGGGACATAGC & 124 \\
\hline \multirow{2}{*}{ TXNIP } & \multirow{2}{*}{ XM_032204531.1 } & Forward & GCTGCCAAGAAGGAGAAGAAGGTG & 130 \\
\hline & & Reverse & TGTTCTCGAAGTCGGCGTTGATG & 130 \\
\hline \multirow{2}{*}{ Caspase-1 } & \multirow{2}{*}{ XM_027446016.1 } & Forward & GCGGAACCAAGAGCAGAGATGAG & 130 \\
\hline & & Reverse & CCACGGCAGGACTGGATAATAACC & 130 \\
\hline \multirow{2}{*}{ IL-18 } & & Forward & GGCTCTGTCCCAAGGCAGGAG & 124 \\
\hline & NM_001310420.1 & Reverse & GCCACTCTGCGTCAGCTTCAC & 124 \\
\hline & & Forward & ATGTGCGAGAAGTTCACCGTCTG & 113 \\
\hline IL-6 & JQ728554.1 & Reverse & TCGTCGAAGCCAGCCAGGAG & 113 \\
\hline & & Forward & AGCTGGCTAAGACCGTGGTCAG & 151 \\
\hline TNF-a & XM_013105371.3 & Reverse & ACGTTGTTGACTCGTCCATGTGAC & 151 \\
\hline & & Forward & GACCTCCAGCACACGAAGTTAGAC & 165 \\
\hline TLR4 & NM_001310413.1 & Reverse & GGAGTTGCCTGCCATCTTGAGC & 165 \\
\hline & & Forward & GGAGCAGTGGCGGTGTCAAC & 126 \\
\hline NF-kB & XM_027453277.2 & Reverse & AGTGCAGTTCATGTCATCGGTCTC & 126 \\
\hline & & Forward & ATGTCGCCCTGGATTTCG & 62 \\
\hline$\beta$-actin & EF667345.1 & Reverse & CACAGGACTCCATACCCAAGAA & 62 \\
\hline
\end{tabular}

\subsection{Statistical Analysis}

The experiment data were obtained by at least six times and each sample was measured three times. Analysis of the research data using Independent-Samples T Test by SPSS (Version 22.0, SPSS Inc., Chicago, IL, USA) with $5 \%$ probability of error and statistical significance was $p<0.05$ in this study. 


\section{Results}

\subsection{Intestinal Morphology}

In this study, histopathological examination (H\&E) and the destruction of the microstructure assessed by an ultrastructural of ileum had been demonstrated in Figure 1. Compared to the $\mathrm{T}_{0}$ group, the ileum in the $\mathrm{T}_{0}+\mathrm{AFB} 1$ group showed the epithelial thickness reduction, the villi structure damage and the inflammatory cell aggregation and the microstructure destruction, such as a large number of microvilli severely broken and mitochondria swelled and shrinkage. The damage in ileum of ducks containing structural destruction of villi and microvilli after AFB1 administration induced the appearance of inflammation and oxidation stress. As expected, dietary curcumin had an ability to protect the ileum against acute damage induced by AFB1 administration, including few of ileum villi broken, inflammatory cell gathered and a little damage of ileum structure evaluated by $\mathrm{H} \& \mathrm{E}$, and decreasing the number of broken microvilli, reducing mitochondrial swelling and eliminating mitochondrial shrinkage assessed by an ultrastructural as shown in structure difference between the $\mathrm{T}_{500}+\mathrm{AFB} 1$ group and the $\mathrm{T}_{0}+\mathrm{AFB} 1$ group.
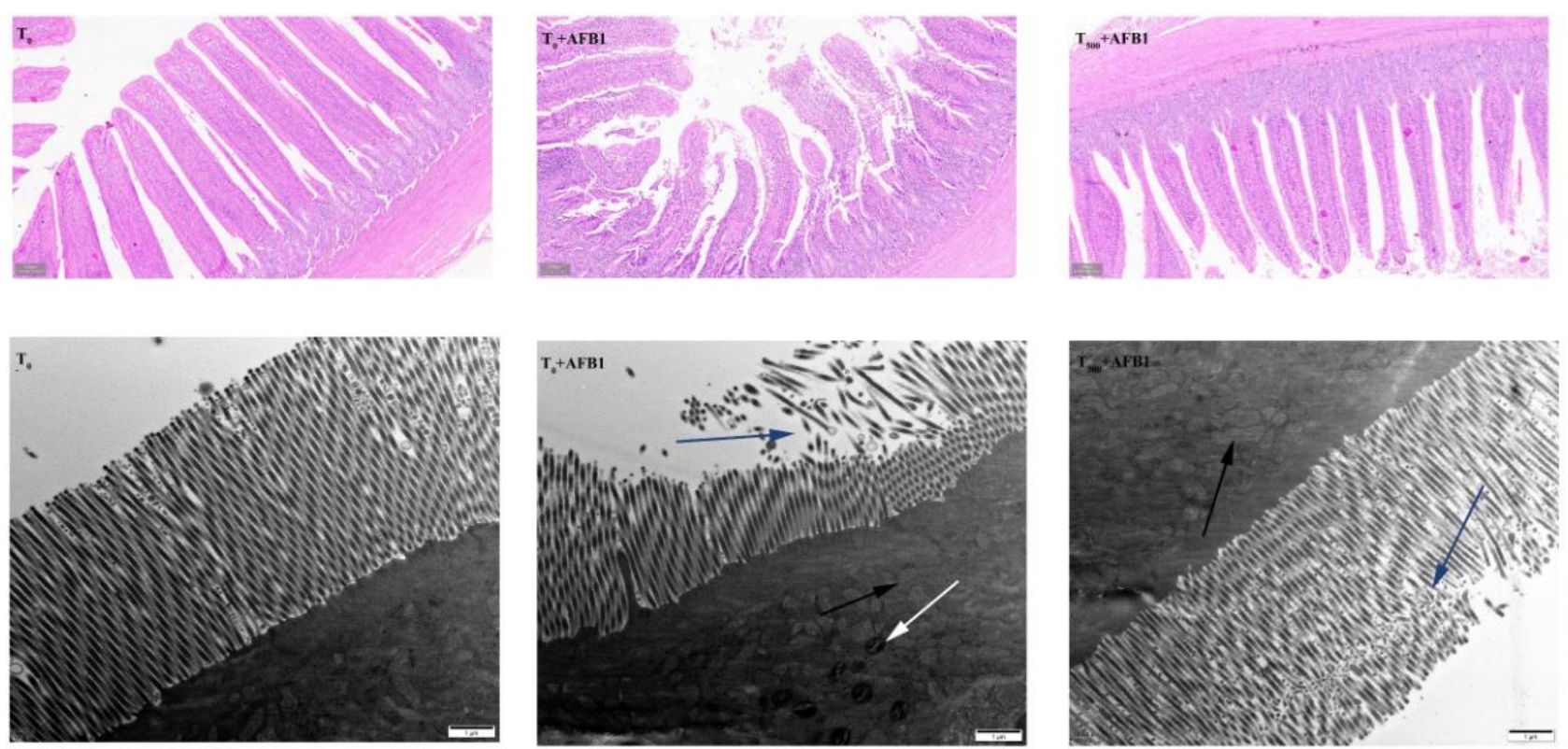

Figure 1. Ileum histopathological examination and scanning electron microscope of ducks (Anas PlatyrhynchosI) exposed to AFB1 at 70 days. The black arrowhead indicated swollen mitochondria, the white arrowhead indicated the shrinkage of mitochondrial and the blue arrowhead indicated broken of intestinal microvilli. $\mathrm{T}_{0}$ : the control group, $\mathrm{T}_{0}+\mathrm{AFB} 1$ : AFB1 group; $\mathrm{T}_{500}+\mathrm{AFB1}$ : curcumin + AFB1 group.

\subsection{Levels of AFB1-DNA Adducts in the Plasma}

AFB1-DNA adducts in the plasma of ducks was measured by indirect competitive ELISA and shown in Figure 2. Compared to the $\mathrm{T}_{0}$ group, AFB1 administration significantly increased the content of AFB1-DNA adducts $(p<0.001)$ in the plasma. As expected, dietary curcumin reduced AFB1-DNA adducts content $(p=0.001)$ in the plasma of ducks in the $\mathrm{T} 500+\mathrm{AFB} 1$ group relative to that in the $\mathrm{T}_{0}+\mathrm{AFB1}$ group. 


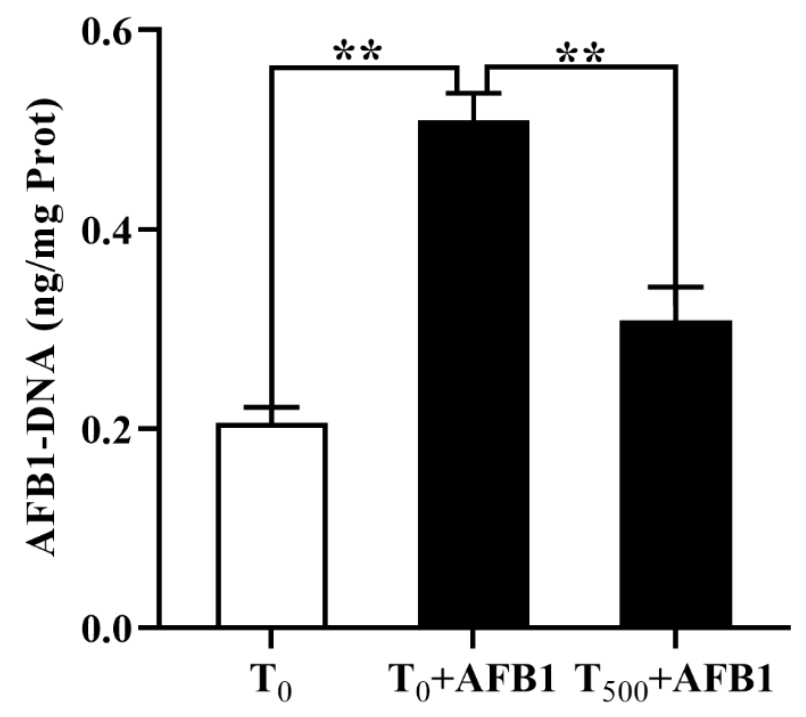

Figure 2. The aggregation of AFB1-DNA adducts in the plasma of ducks (Anas PlatyrhynchosI) exposed to AFB1 at 70 days. $\mathrm{T}_{0}$ : the control group, $\mathrm{T}_{0}+\mathrm{AFB1}$ : AFB1 group; $\mathrm{T}_{500}+\mathrm{AFB} 1$ : curcumin + AFB1 group. Values are expressed as Mean $\pm \operatorname{SEM}(n=15),{ }^{* *}$ means $p<0.01$.

\subsection{Antioxidant Capacity in the Plasma and Ileum}

The antioxidant capacity of the plasma was shown in Figure 3. Exposure of AFB1 led to oxidation stress, manifesting that the T-SOD ( $p=0.073)$, GSH-PX $(p=0.034)$ and GSH-ST $(p=0.003)$ activities in the plasma were decreased in the $\mathrm{T}_{0}+$ AFB1 group than those in the $\mathrm{T}_{0}$ group. However, the T-SOD $(p=0.039)$, GSH-PX $(p=0.009)$ and GSH-ST $(p=0.003)$ activities were significantly enhanced in the $\mathrm{T}_{500}+$ AFB1 group than those in the $\mathrm{T}_{0}+$ AFB1 group. The concentration of MDA $(p=0.028)$ in the plasma was increased in the $\mathrm{T}_{0}+\mathrm{AFB} 1$ group than that in the $\mathrm{T}_{0}$ group, and the concentration of MDA $(p<0.001)$ in the plasma was decreased in the $\mathrm{T}_{500}+\mathrm{AFB1}$ group than those in the $\mathrm{T}_{0}+\mathrm{AFB1}$.

A

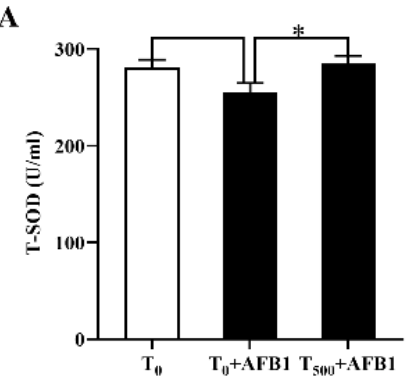

$\mathbf{E}$

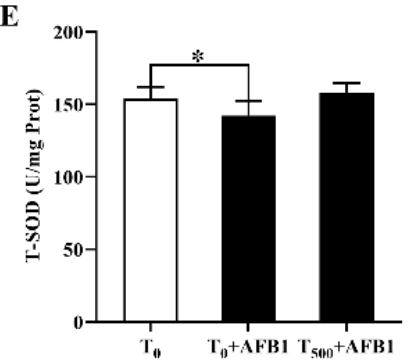

B

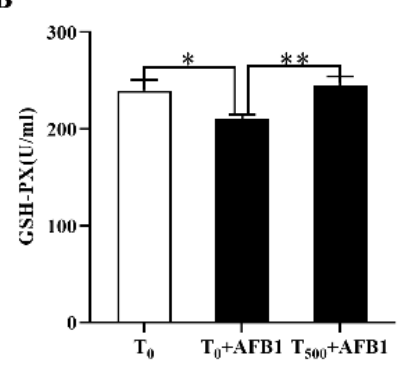

F

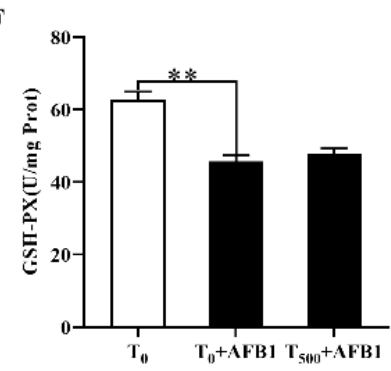

C

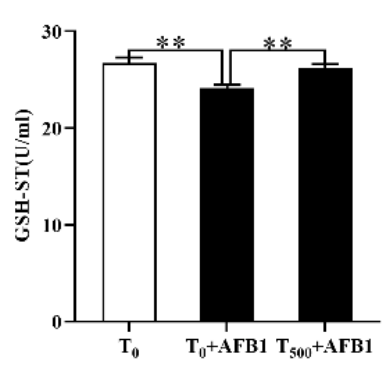

G

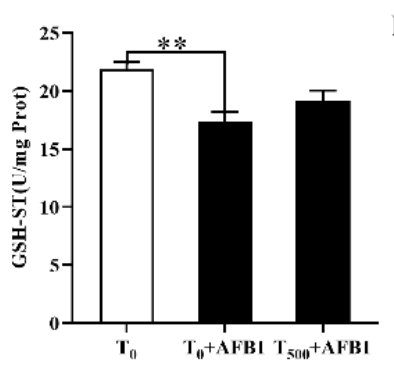

D

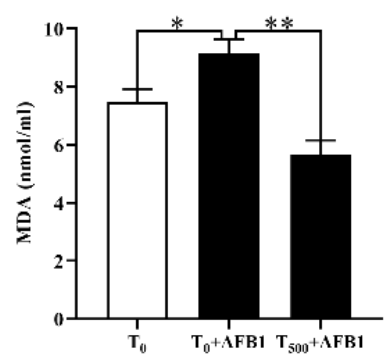

H

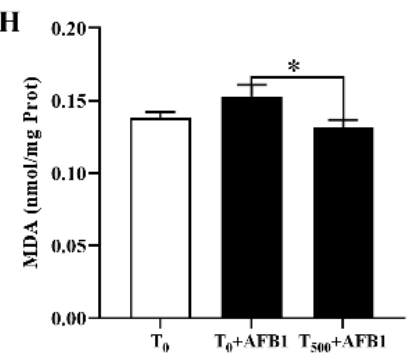

Figure 3. Antioxidant capacity of the plasma and ileum of ducks (Anas PlatyrhynchosI) exposed to AFB1 at 70 days. $\mathrm{T}_{0}$ : the control group, $\mathrm{T}_{0}+\mathrm{AFB} 1$ : AFB1 group; $\mathrm{T}_{500}+\mathrm{AFB1}$ : curcumin + AFB1 group. T-SOD, Total Superoxide Dismutase; GSH-PX, Glutathione Peroxidase; GSH-ST, Glutathione S-transferase; MDA, Malondialdehyde. (A-D) means antioxidant capacity in the plasma, (E-H) means antioxidant capacity in the ileum. Values are expressed as Mean \pm SEM $(n=15)$, and ${ }^{*}$ means $p<0.05,{ }^{* *}$ means $p<0.01$. 


\subsection{Expression of Genes Related to Nrf2-ARE Signaling Pathway in the Ileum}

AFB1 administration induced the cell oxidation stress and further resulted in the expression changes of genes including Keap1, Nrf2, CAT, SOD1, GPX, GST, NQO-1, HO-1, GCLC and GCLM in the ileum of ducks. As shown in Figure 4, AFB1 administration significantly increased the mRNA $(p=0.001)$ level of Keap1 gene, and inhibited mRNA levels of genes including Nrf2 $(p=0.171), \operatorname{CAT}(p=0.166), \operatorname{SOD} 1(p=0.121), \operatorname{GPX}(p=0.065)$, GST $(p=0.008)$, NQO-1 $(p=0.061)$, HO-1 $(p=0.068)$, GCLC $(p=0.800)$ and GCLM $(p=0.090)$ and Nrf2 protein content $(p=0.001)$ in the ileum of ducks in the $\mathrm{T}_{0}+$ AFB1 group relative to those in the $\mathrm{T}_{0}$ group. As expected, adding curcumin into diet fed ducks for 70 days significantly decreased the mRNA $(p=0.012)$ expression of Keap1 gene in ileum, significantly increased mRNA level of genes including Nrf2 $(p=0.042)$, SOD1 $(p=0.038)$, HO-1 ( $p=0.041)$, NQO-1 $(p=0.047)$ and GCLC $(p=0.043)$, and improved mRNA level of genes including CAT $(p=0.229), \operatorname{GPX}(p=0.568), \operatorname{GST}(p=0.454)$ and GCLM $(p=0.860)$, and Nrf2 protein $(p=0.005)$ in ileum of ducks in the $T_{500}+$ AFB1 group relative to those in the $\mathrm{T}_{0}+\mathrm{AFB} 1$ group.
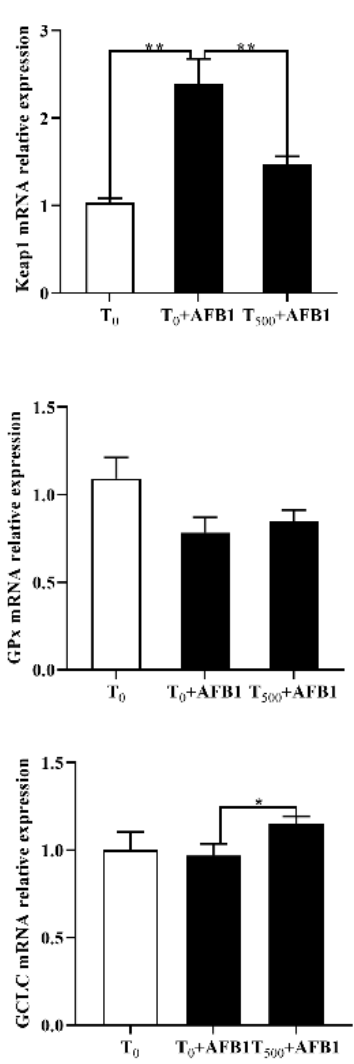

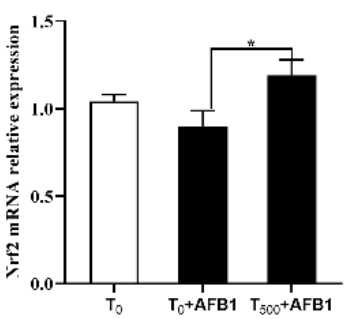

F

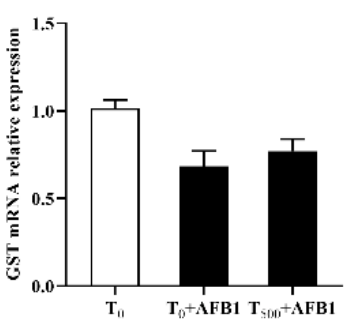

$\mathbf{J}$

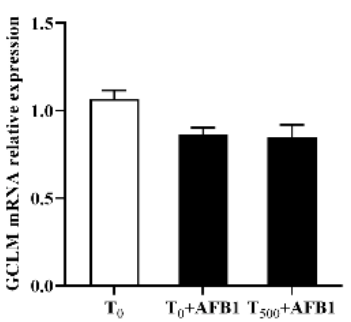

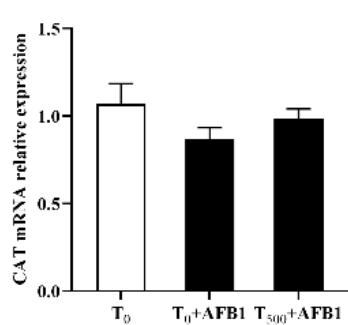

G

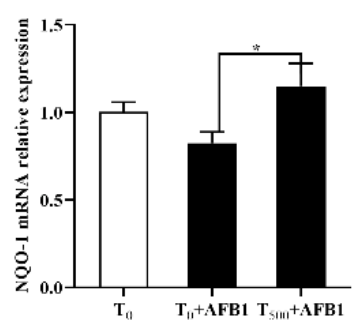

$\mathbf{K}$

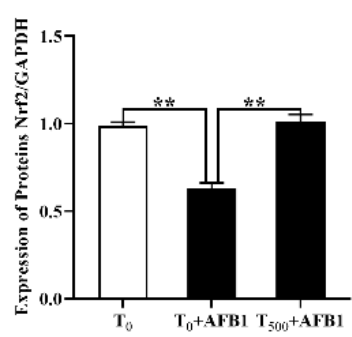

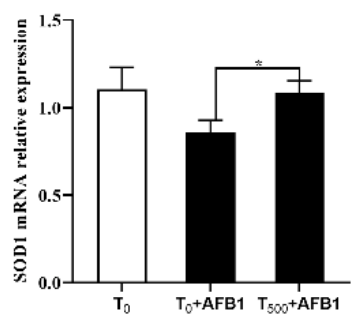

H

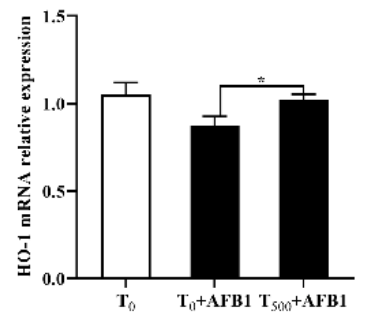

L

Nrf2

GAPDH

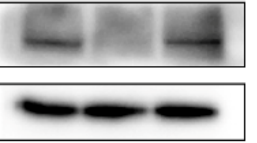

Figure 4. mRNA and protein expression of genes related to Nrf2-ARE signaling pathway in the ileum of ducks (Anas PlatyrhynchosI) exposed to AFB1 at 70 days. $\mathrm{T}_{0}$ : the control group, $\mathrm{T}_{0}+\mathrm{AFB1}$ : AFB1 group; $\mathrm{T}_{500}+\mathrm{AFB} 1$ : curcumin + AFB1 group. Keap1, Kelch-like ECH-associated protein (A); Nrf2, Nuclear factor erythroid 2-related factor 2 (B); CAT, Catalase (C); SOD, Superoxide dismutase (D); GPx, Glutathione peroxidase (E); GST, Glutathione S-transferase (F); NQO1, $\mathrm{NAD}(\mathrm{P}) \mathrm{H}$ quinone oxidoreductase $1(\mathbf{G})$; HO-1, Heme oxygenase 1 (H); GCLC, Glutamate cysteine ligase catalyzes subunits (I); GCLM, Glutamic acid cysteine ligase modified subunit (G); GAPDH, Glyceraldehyde-3-phosphate dehydrogenase (K). Genes including the enzymatic antioxidant system (CAT, SOD1, GPX and GST) and phase II detoxification enzymes (NQO-1, HO-1, GCLC and GCLM). The relative expression of Nrf2 protein in the ileum were expressed as the ratio of band intensity of the target protein to internal reference (GAPDH) $(\mathbf{K}, \mathbf{L})$. Values were expressed as Mean \pm SEM $(n=15)$, and * means $p<0.05,{ }^{* *}$ means $p<0.01$. 


\subsection{Expression of Genes Related to NF- $\kappa B$ Signaling Pathway in the Ileum}

The expression of inflammatory genes was shown in the Figure 5 . Compared to the $T_{0}$ group, AFB1 administration increased mRNA level of some genes such as TLR4 ( $p=0.037)$, NF-kB $(p<0.001)$, TNF- $\alpha(p=0.025)$, IL-6 $(p=0.072)$, TXNIP $(p=0.007)$, NLRP3 $(p<0.001)$ and IL-18 $(p=0.478)$ in the ileum of ducks in the $\mathrm{T}_{0}+$ AFB1 group. As expected, dietary curcumin significantly suppressed over-expression of genes including TLR4 $(p<0.001)$, NF-KB $(p=0.001)$, TNF- $\alpha(p=0.012), \operatorname{IL}-6(p=0.007)$, TXNIP $(p=0.001), \operatorname{NLRP3}(p=0.001)$ and IL-18 $(p<0.001)$ in the ileum of ducks in the T500 + AFB1 group relative to those in the $\mathrm{T}_{0}+$ AFB1 group. In addition, the contents of P-P $65(p=0.004)$ in the ileum increased in the $\mathrm{T}_{0}+$ AFB1 group relative to that in the $\mathrm{T}_{0}$ group. As expected, dietary curcumin significantly suppressed P-P $65(p=0.015)$ protein content.

A

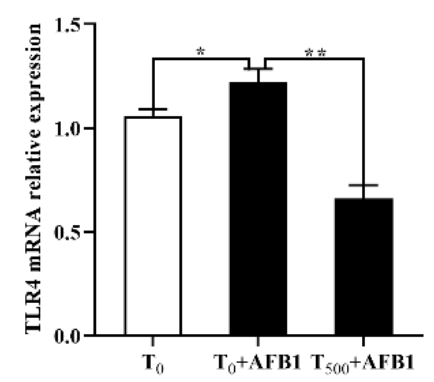

D

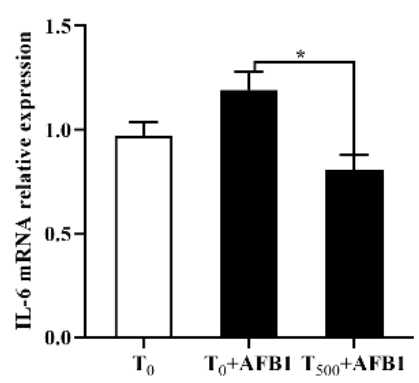

G

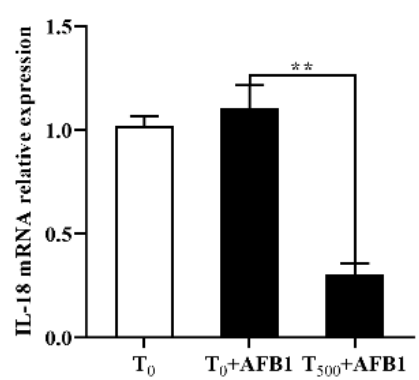

B

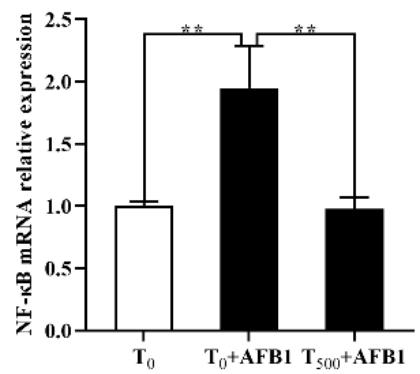

E

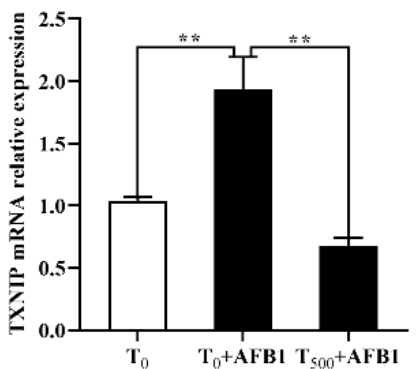

H

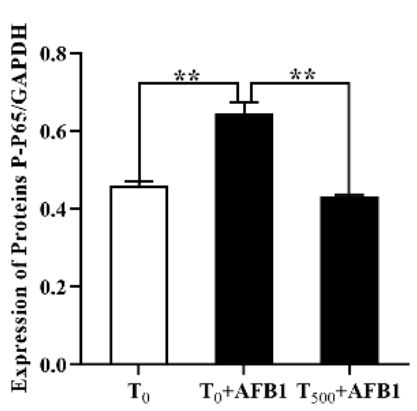

C

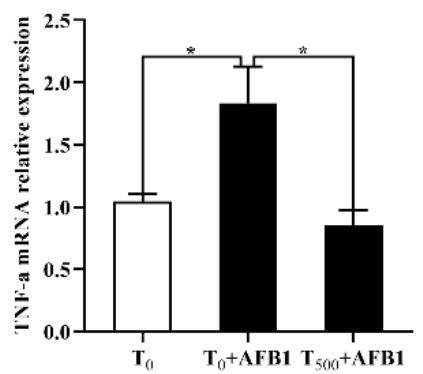

F

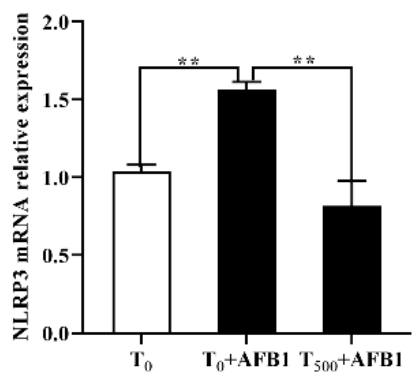

I

P-P65

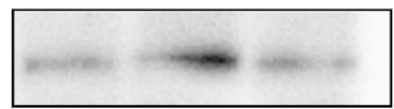

GAPDH

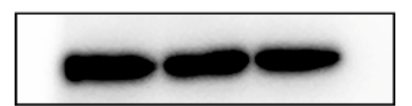

Figure 5. mRNA and protein levels of genes related to NF-kB signaling pathway in the ileum of ducks (Anas PlatyrhynchosI) exposed to AFB1 at 70 days. $\mathrm{T}_{0}$ : the control group, $\mathrm{T}_{0}+\mathrm{AFB1}$ : $\mathrm{AFB} 1$ group; $\mathrm{T}_{500}+\mathrm{AFB1}$ : curcumin $+\mathrm{AFB} 1$ group. TLR4, toll like reporter 4 (A); NF-kB, Nuclear factor kB (B); TNF- $\alpha$, Tumor Necrosis Factor- $\alpha$ (C); Il-6, Interleukin -6 (D); TXNIP, thioredoxin interacting protein (E); NLRP3, NOD-like receptor family pyrin domain containing protein 3 (F); Il-18, Interleukin -18; P-P 65 (G), Phospho-NF-kB p65 (Ser276) rabbit polyclonal antibody (H); (I) GAPDH, Glyceraldehyde3-phosphate dehydrogenase. The relative expression of P-P65 protein in the ileum was expressed as the ratio of band intensitiy of the target protein to the internal reference (GAPDH). Values were expressed as Mean $\pm \operatorname{SEM}(n=15)$, and ${ }^{*}$ means $p<0.05,{ }^{* *}$ means $p<0.01$. 


\section{Discussion}

Intestinal morphology is one of behavioral markers to evaluate inflamation and oxidation stress of intestine induced by AFB1 administration. Literatures on the effects of AFB1 adnimistration on ileum morphology of ducks are scantly. Yan et al. (2020) reported that AFB1 administration led to cardiac pathologic damage of Sprague-Dawley rats, inflammatory cell infiltration and greater cardiomyocyte degeneration [29]. Catarrhal enteritis with inflammatory cell infiltrations in the intestine of broiler chickens induced by AFB1 destroyed the structure of intestine [12]. Luzi et al. (2002) reported acute AFB1 administration induced the ileum contractions [30]. The results in this study demonstrated that dietary curcumin is a potent protective agent of ileum agaisnt inhibiting inflamation, which may be that curcumin had an ability to inhibite anti-inflammatory in multiple inflammatory disordies in mice [31-33].

DNA damage caused by oxidative stress will destruct the stability of DNA, which can promote the formation of various DNA adducts [34]. AFB1-DNA adducts is a biomarker to evaluate the injury degree of body which was induced by AFB1. Synthesizing and enriching of AFB1-DNA adducts destroyed the structure of tissues, then resulting in carcinogenic development [35]. AFB1 would be metabolized by cytochrome P450s isoenzymes to AFB1-8,9-epoxide (AFBO) and produce related adducts [36] and increase tissues damage, oxidative stress and DNA damage by ROS [37]. AFB1-DNA adducts can bound with the nucleoproteins and nucleic acids, thus induce DNA and cell damages and decrease the level of antioxidant enzymes and the protein synthesis [38]. Zhang et al. (2016) reported that curcumin-supplemented inhibited liver damage induced by AFB1 by increasing antioxidation activity of antioxidant enzymes (GPx, SOD, CAT and GST) and inhibiting AFB1-DNA production [39]. In this study, AFB1 administration increased AFB1-DNA adducts content in the plasma. Dietary curcumin significantly diminished this phenomenon, results demonstrated that dietary curcumin was potential to protect ileum in this acute AFB1 administration model that may be explained by the antioxidant effect of curcumin that improved the antioxidation capacity of body $[40,41]$.

Oxidation stress occurred when the imbalance of oxidation and antioxidation in bodies induced by the decreases of antioxidant enzyme activities and the increases in lipid peroxidation levels. Antioxidant enzyme system including CAT, GSH-Px and SOD is the first line of cell defenses against free radicals and reactive oxygen species (ROS) and is indispensable in the entire defense strategy of antioxidants in the body [42]. GST is a crucial enzyme to downregulate reactive oxygen species (ROS) and oxidative stress in order to achieve detoxification for bodies [43]. As shown in Figure 3, oxidation stress in plasma and ileum of ducks occurred during acute ileum damage induced by AFB1 administration. As expected, dietary curcumin ameliorated oxidation stress of bodies by increasing T-SOD, GSH-PX and GSH-ST activities in the plasma and ileum after AFB1 administration. The results in this study demonstrated that the curcumin is a potent anti-oxidation agent for ducks fed AFB1 administration that may be explained by the anti-oxidative capacity via suppressing lipid oxidation and increasing antioxidation enzyme activity by curcuminsupplemented $[8,44,45]$. These results are in line with a previous report that demonstrated that curcumin ameliorated AFB1-induced alteration in glutathione, SOD, CAT and MDA activities [8]. This may be due to the ability of curcumin to scavenge free radicals by restoring antioxidant enzymes activities and alleviated oxidative stress [15,46].

The balance between oxidation and anti-oxidation in vivo were regulated by T-SOD and GSH-Px [47]. Nrf2 was translocated into the cell nucleus and combined with $t$ antioxidant response element (ARE) and upregulated the transcription of the antioxidant enzyme genes including SOD, CAT, GSH-Px, HO-1, NQO-1, GCLC and GCLM [47,48]. In addition, GST is upregulated by activating Nrf2 signaling way and as a kind of phase-II detoxifying enzyme involved in various detoxification in vivo to relieve oxidative stress [49,50]. Oxidative stress and lipid peroxidation were biomarkers for rats induced by AFB1 administration [51,52]. Oxidative stress was diminished by activation genes expression under Nrf2-ARE signaling pathway, such as NQO-1, HO-1 and GCLC [40]. Numerous research 
reported that curcumin-supplemented induced genes expression including HO-1, NQO-1, $\gamma$-GCLC, $\gamma$-GCLM, CAT and GPX via Nrf2 activation in broiler and rats [40,41] and eliminated liver damage induced by AFB1 administration $[39,53]$. The results in this study indicated that AFB1 administration may induce oxidation stress damage of ileum via inhibiting Nrf2 signaling pathway. Dietary curcumin promoted Nrf2 downstream genes expression such as antioxidant genes (CAT, SOD1, GPX1, GST) and phase II detoxifying enzyme genes (NQO1, HO-1, GCLC, GCLM), which demonstrated that adding curcumin into diet for ducks inhibited the acute oxidation damage of ileum induced by AFB1 administration through activating Nrf2-ARE signaling pathway Results in this study provided an evidence that dietary curcumin could be a potent ameliorating agent to protect ileum against oxidation stress induced by AFB1 administration.

Oxidation stress activated NF- $\mathrm{KB}$ signaling pathway then further evaluated the production of inflammatory cytokines [54]. In this study, ileum injury induced by AFB1 administration may be due to the inflammation. AFB1 administration may induce ileum damage directly via increasing expression of inflammatory factors, and directly activating the inflammatory signaling pathway. There is a positive relationship between the oxidation stress and the inflammation in tissues [55]. Ko et al. (2020) reported that oxidation stress activated NF- $\mathrm{kB}$ signaling pathway, upregulated pro-inflammatory cytokines and caused inflammation in rat lung [56]. The NF- $\mathrm{KB}$ signaling could be activated by AFB1 in the cell line 3D4/21 [57], resulting a series of inflammatory reactions [58]. Kumara et al. (2020) found that AFB1 administration induced the inflammatory by elevating levels of pro-inflammatory factors cytokines, TNF- $\alpha$, IL-12 and IL-6 in the serum of albino mice [59]. Dietary AFB1 exposure resulted in genes over-expression of TNF- $\alpha$, IL-1 $\beta$ and IL- 6 in the liver of pigs, and the mRNA levels of inflammatory factors (TNF- $\alpha$, IL-12, IL-6) in the liver of pigs fed the diet containing $8 \%$ grape seed meal and AFB1 returned to the control levels [60]. The levels of TNF- $\alpha$, IL- 6 and IL- $1 \beta$ in the liver of rats with intra-uterine growth retardation were increased, which in the liver of IUGR rats fed with curcumin $400 \mathrm{mg} \mathrm{kg}^{-1}$ diet returned to the control level of normal birth weight rats [38]. The activation of NF- $\mathrm{kB}$ signaling pathway upregulated genes expression (NLRP3 and Caspase-1), which promoted IL-1 $\beta$ and IL-18 maturation and secretion and triggered an inflammatory response [61]. Results in this study demonstrated that AFB1 administration significantly evaluated gene expression of inflammation factors in the ileum of ducks, and dietary curcumin inhibited these gene expression, in line with a study that the activation of NLRP3 signaling pathway by AFB1 in rats [40]. Previous results showed that curcumin had an ability to inhibit NLRP3 protein expression via suppressing caspase-1 and IL-1 $\beta$ [29]. Thus, results in this study revealed that curcumin may be one of the promising feed additives to relieve inflammation in ileum and ileum damage induced by AFB1 administration by inhibiting NF- $\mathrm{kB}$ signaling pathway.

\section{Conclusions}

In conclusion, AFB1 administration induced ileum injury, oxidation stress and inflammation via inhibiting expression of downstream genes of Nrf2-ARE signaling pathway and activating genes expression of downstream genes of NF- $\mathrm{kB}$ signaling pathway. However, dietary curcumin markedly ameliorated ileum damage, oxidation stress and inflammation of ducks induced by AFB1 administration, possible due to activate Nrf2-ARE and inhibit NF- $\mathrm{kB}$ signaling pathway (Figure 6). Results in this study provided a powerful evident that dietary curcumin is an effective feed additive to protect the ileum against acute injury induced by AFB1 administration via activating Nrf2-ARE and inhibiting NF- $\kappa B$ signaling pathway. 


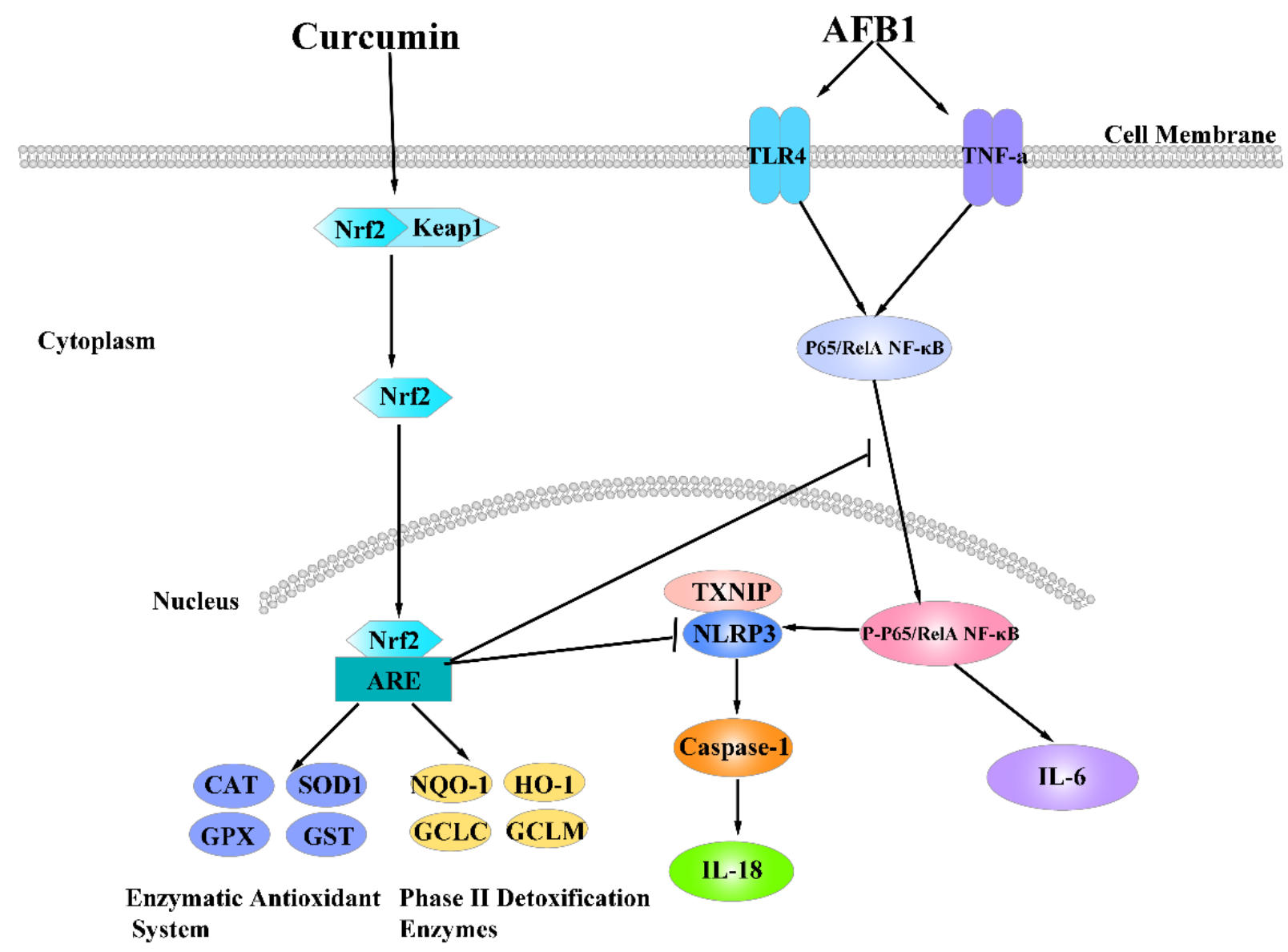

Figure 6. The antioxidant damage mechanism of dietary curcumin through Nrf2-ARE signaling pathway to elevate the expression of its downstream genes, including the antioxidant enzymatic system (CAT, SOD1, GPX and GST) and phase II detoxification enzymes (NQO-1, HO-1, GCLC and GCLM), as well as anti-inflammatory mechanism via inhibiting expression of genes related to NF- $\mathrm{KB}$ signaling pathway.

Author Contributions: Conceptualization: S.J. and X.F.; methodology: S.J. and H.Y.; validation: S.J., H.Y. and Y.J.; formal analysis: S.J. and H.Y.; resources: X.F.; data curation: S.J. and X.F.; writingoriginal draft preparation: S.J.; writing—review and editing: X.F.; project administration: Q.P., Y.W., M.W. and A.S.; funding acquisition: X.F.; All authors have read and agreed to the published version of the manuscript.

Funding: This work was supported by the National Natural Science Foundation of China (31772638, 32072768) and the Natural Science Foundation of Heilongjiang Province (C2016022).

Informed Consent Statement: The study was conducted according to the guidelines of the practices outlined in the Guide for the Care and Use of Agricultural Animals in Agriculture Research and Teaching of Northeast Agricultural University (Protocol number: NEAU-(2011)-9).

Data Availability Statement: The raw data presented in this study are available on request from the corresponding author.

Conflicts of Interest: The authors declare no conflict of interest. 


\section{References}

1. Khan, M.A.; Ali, S.; Yang, H.; Kamboh, A.A.; Ahmad, Z.; Tume, R.K.; Zhou, G. Improvement of color, texture and food safety of ready-to-eat high pressure-heat treated duck breast. Food Chem. 2019, 277, 646-654. [CrossRef]

2. Kos, J.; Janic Hajnal, E.; Malachova, A.; Steiner, D.; Stranska, M.; Krska, R.; Poschmaier, B.; Sulyok, M. Mycotoxins in maize harvested in republic of serbia in the period 2012-2015. Part 1: Regulated mycotoxins and its derivatives. Food Chem. 2020, 312, 126034. [CrossRef]

3. Wangia, R.N.; Tang, L.; Wang, J.S. Occupational exposure to aflatoxins and health outcomes: A review. J. Environ. Sci. Health Part C Environ. Carcinog. Rev. 2019, 37, 215-234. [CrossRef]

4. Vineis, W.; Xun, P.V. The emerging epidemic of environmental cancers in developing countries. Ann. Oncol. 2009, 20, 205-212. [CrossRef] [PubMed]

5. Robert, H.; Payros, D.; Pinton, P.; Théodorou, V.; Mercier-Bonin, M.; Oswald, I.P. Impact of mycotoxins on the intestine: Are mucus and microbiota new targets? J. Toxicol. Environ. Health Part B Crit. Rev. 2017, 20, 249. [CrossRef] [PubMed]

6. Ishfaq, M.; He, W.; Sun, X.; Wang, X.; Han, M.; Lu, Z. Dual role of dietary curcumin through attenuating afb1-induced oxidative stress and liver injury via modulating liver phase-i and phase-ii enzymes involved in afb1 bioactivation and detoxification. Front. Pharmacol. 2018, 9, 554 .

7. Jager, A.V.; Tonin, F.G.; Baptista, G.Z.; Souto, P.C.; Oliveira, C.A. Assessment of aflatoxin exposure using serum and urinary biomarkers in sao paulo, brazil: A pilot study. Int. J. Hyg. Environ. Health 2016, 219, 294-300. [CrossRef] [PubMed]

8. Li, S.; Muhammad, I.; Yu, H.; Sun, X.; Zhang, X. Detection of aflatoxin adducts as potential markers and the role of curcumin in alleviating AFB1-induced liver damage in chickens. Ecotoxicol. Environ. Saf. 2019, 176, 137-145. [CrossRef] [PubMed]

9. Wijtten, P.J.; van der Meulen, J.; Verstegen, M.W. Intestinal barrier function and absorption in pigs after weaning: A review. Br. J. Nutr. 2011, 105, 967-981. [CrossRef] [PubMed]

10. Wu, Y.; Liu, W.; Li, Q.; Li Y., F.; Yan, Y.L.; Huang, F.; Wu, X.; Zhou, Q.C.; Shu, X.G.; Ruan, Z. Dietary chlorogenic acid regulates gut microbiota, serum-free amino acids and colonic serotonin levels in growing pigs. Int. J. Food Sci. Nutr. 2017, 1-8. [CrossRef]

11. Wang, F.; Zuo, Z.; Chen, K.; Gao, C.; Yang, Z.; Zhao, S.; Li, J.; Song, H.; Xi, P.; Jing, F. Histopathological Injuries, Ultrastructural Changes, and Depressed TLR Expression in the Small Intestine of Broiler Chickens with Aflatoxin B1. Toxins 2018, 10, 131. [CrossRef] [PubMed]

12. Zhang, S.; Peng, X.; Fang, J.; Cui, H.; Zuo, Z.; Chen, Z. Effects of aflatoxin B1 exposure and sodium selenite supplementation on the histology, cell proliferation, and cell cycle of jejunum in broilers. Biol. Trace Elem. Res. 2014, 160, 32. [CrossRef] [PubMed]

13. Kumar, R.; Balachandran, C. Histopathological changes in broiler chickens fed aflatoxin and cyclopiazonic acid. Vet. Arh. 2009, $79,31-40$.

14. Pandey, A.; Gupta, R.K.; Srivastava, R. Curcumin-the yellow magic. Asian J. Appl. Sci. 2011, 4, 343-354. [CrossRef]

15. Wang, Y.; Wang, M.; Shan, A.; Feng, X. Avian host defense cathelicidins: Structure, expression, biological functions, and potential therapeutic applications. Poult. Sci. 2020, 99, 6434-6445. [CrossRef]

16. Menon, V.P.; Sudheer, A.R. Antioxidant and anti-inflammatory properties of curcumin. Oxyg. Transp. Tissue XXXIII 2007, 595, 105-125.

17. He, Y.; Yue, Y.; Zheng, X.; Zhang, K.; Chen, S.; Du, Z. Curcumin, inflammation, and chronic diseases: How are they linked? Molecules 2015, 20, 26007179. [CrossRef]

18. Soliman, M.; Nassan, M.; Ismail, T. Immunohistochemical and molecular study on the protective effect of curcumin against hepatic toxicity induced by paracetamol in Wistar rats. BMC Complement. Altern. Med. 2014, 14, 457. [CrossRef]

19. Schwarz, K.; Dobiasch, S.; Nguyen, L.; Schilling, D.; Combs, S.E. Modification of radiosensitivity by Curcumin in human pancreatic cancer cell lines. Sci. Rep. 2020, 10, 3815. [CrossRef]

20. Aggarwal, B.B.; Harikumar, K.B. Potential Therapeutic Effects of Curcumin, the Anti-Inflammatory Agent, Against Neurodegenerative, Cardiovascular, Pulmonary, Metabolic, Autoimmune and Neoplastic Diseases. Int. J. Biochem. Cell Biol. 2009, 41, 40-59. [CrossRef]

21. Abrahams, S.; Haylett, W.L.; Johnson, G.; Carr, J.A.; Bardien, S. Antioxidant effects of curcumin in models of neurodegeneration, aging, oxidative and nitrosative stress: A review. Neuroscience 2019, 406, 1-21. [CrossRef]

22. Nakmareong, S.; Kukongviriyapan, U.; Pakdeechote, P.; Donpunha, W.; Kukongviriyapan, V.; Kongyingyoes, B.; Sompamit, K.; Phisalaphong, C. Antioxidant and vascular protective effects of curcumin and tetrahydrocurcumin in rats with L-NAME-induced hypertension. Naunyn Schmiede. Arch. Pharm. 2011, 383, 519-529. [CrossRef] [PubMed]

23. Topcu-Tarladacalisir, Y.; Akpolat, M.; Uz, Y.H.; Kizilay, G.; Sapmaz-Metin, M.; Cerkezkayabekir, A.; Omurlu, I.K. Effects of curcumin on apoptosis and oxidoinflammatory regulation in a rat model of acetic acid-induced colitis: The roles of c-Jun N-terminal kinase and p38 mitogen-activated protein kinase. J. Med. Food 2013, 16, 296-305. [CrossRef] [PubMed]

24. Rahmani, A.H.; Alsahli, M.; Aly, S.M.; Khan, M.A.; Aldebasi, Y.H. Role of Curcumin in Disease Prevention and Treatment. Adv. Biomed. Res. 2018, 7, 38. [CrossRef] [PubMed]

25. Limaye, A.; Yu, R.C.; Chou, C.C.; Liu, J.R.; Cheng, K.C. Protective and Detoxifying Effects Conferred by Dietary Selenium and Curcumin against AFB1-Mediated Toxicity in Livestock: A Review. Toxins 2018, 10, 25. [CrossRef]

26. Soetikno, V.; Sari, F.R.; Lakshmanan, A.P.; Arumugam, S.; Harima, M.; Suzuki, K.; Kawachi, H.; Watanabe, K. Curcumin alleviates oxidative stress, inflammation, and renal fibrosis in remnant kidney through the Nrf2-keap1 pathway. Mol. Nutr. Food Res. 2013, 57, 1649-1659. [CrossRef] 
27. Wang, D.; Huang, H.; Zhou, L.; Li, W.; Zhou, H.; Hou, G.; Liu, J.; Hu, L. Effects of dietary supplementation with turmeric rhizome extract on growth performance, carcass characteristics, antioxidant capability, and meat quality of wenchang broiler chickens. Ital. J. Anim. Sci. 2016, 14, 344-349. [CrossRef]

28. Jin, S.; Pang, Q.; Liu, R.; Yang, H.; Liu, F.; Wang, M.; Wang, Y.; Feng, X.; Shan, A. Dietary curcumin decreased lipid oxidation and enhanced the myofibrillar protein structure of the duck (Anas platyrhynchos) breast muscle when subjected to storage. LWT-Food Sci. Technol. 2020, 133, 1-7. [CrossRef]

29. Yan, H.; Ge, J.; Gao, H.; Pan, Y.; Hao, Y.; Li, J. Melatonin attenuates AFB1-induced cardiotoxicity via the NLRP3 signalling pathway. J. Med. Internet Res. 2020, 48, 300060520952656. [CrossRef]

30. Luzi, A.; Cometa, M.F.; Palmery, M. Acute effects of aflatoxins on guinea pig isolated ileum. Toxicol. Vitr. Int. J. Publ. Assoc. Bibra 2002, 16, 525-529. [CrossRef]

31. Zhao, J.; Wang, J.; Zhou, M.; Li, M.; Li, M.; Tan, H. Curcumin attenuates murine lupus via inhibiting NLRP3 inflammasome. Int. Immunopharmacol. 2019, 69, 213-216. [CrossRef]

32. Gong, Z.; Zhou, J.; Li, H.; Gao, Y.; Xu, C.; Zhao, S.; Chen, Y.; Cai, W.; Wu, J. Curcumin suppresses NLRP3 inflammasome activation and protects against LPS-induced septic shock. Mol. Nutr. Food Res. 2015, 59, 2132-2142. [CrossRef]

33. Ruan, Z.; Mi, S.; Zhou, L.; Zhou, Y.; Li, J.; Liu, W.; Yin, Y. Chlorogenic acid enhances intestinal barrier by decreasing MLCK expression and promoting dynamic distribution of tight junction proteins in colitic rats. J. Funct. Foods 2016, 26, 698-708. [CrossRef]

34. Matsui, A.; Hashiguchi, K.; Suzuki, M.; Zhang-Akiyama, Q.M. Oxidation resistance 1 functions in the maintenance of cellular survival and genome stability in response to oxidative stress-independent dna damage. Genes Environ. 2020, 42, 42-49. [CrossRef]

35. Engin, A.B.; Engin, A. DNA damage checkpoint response to aflatoxin B1. Environ. Toxicol. Pharmacol. 2019, 65, 90-96. [CrossRef]

36. Yilmaz, S.; Kaya, E.; Kisacam, M.A. The Effect on Oxidative Stress of Aflatoxin and Protective Effect of Lycopene on Aflatoxin Damage. In Aflatoxin-Control, Analysis, Detection and Health Risks 30; IntechOpen: London, UK, 2017; pp. 67-90.

37. Topal, A.; Alak, G.; Ozkaraca, M.; Yeltekin, A.C.; Comakli, S.; Acil, G.; Kokturk, M.; Atamanalp, M. Neurotoxic responses in brain tissues of rainbow trout exposed to imidacloprid pesticide: Assessment of 8-hydroxy-2-deoxyguanosine activity 2017, oxidative stress and acetylcholinesterase activity. Chemosphere 2017, 175, 186-191. [CrossRef] [PubMed]

38. He, J.; Niu, Y.; Wang, F.; Wang, C.; Cui, T.; Bai, K.; Zhang, J.; Zhong, X.; Zhang, L.; Wang, T. Dietary curcumin supplementation attenuates inflammation, hepatic injury and oxidative damage in a rat model of intra-uterine growth retardation. Br. J. Nutr. 2018, 120, 537-548. [CrossRef]

39. Zhang, N.Y.; Qi, M.; Zhao, L.; Zhu, M.K.; Guo, J.; Liu, J.; Gu, C.Q.; Rajput, S.A.; Krumm, C.S.; Qi, D.S.; et al. Curcumin Prevents Aflatoxin B (1) Hepatoxicity by Inhibition of Cytochrome P450 Isozymes in Chick Liver. Toxins 2016, 8, 327. [CrossRef] [PubMed]

40. Xie, Y.L.; Chu, J.G.; Jian, X.M.; Dong, J.Z.; Wang, L.P.; Li, G.X.; Yang, N.B. Curcumin attenuates lipopolysaccharide/dgalactosamine-induced acute liver injury by activating Nrf2 nuclear translocation and inhibiting NF-kB activation. Biomed. Pharmacother. 2017, 91, 70-77. [CrossRef] [PubMed]

41. Zhang, J.; Bai, K.; Su, W.; Wang, A.; Zhang, L.; Huang, K.; Wang, T. Curcumin attenuates heat-stress-induced oxidant damage by simultaneous activation of GSH-related antioxidant enzymes and Nrf2-mediated phase II detoxifying enzyme systems in broiler chickens. Poult. Sci. 2018, 97, 1209-1219. [CrossRef]

42. Ighodaro, O.M.; Akinloye, O.A. First line defence antioxidants-superoxide dismutase (SOD), catalase (CAT) and glutathione peroxidase (GPX): Their fundamental role in the entire antioxidant defence grid. Alex. J. Med. 2019, 54, 287-293. [CrossRef]

43. Enayati, A.A.; Ranson, H.; Hemingway, J. Insect glutathione transferases and insecticide resistance. Insect Mol. Biol. 2005, 14, 3-8. [CrossRef] [PubMed]

44. Ruan, D.; Zhu, Y.W.; Fouad, A.M.; Yan, S.J.; Chen, W.; Zhang, Y.N.; Xia, W.G.; Wang, S.; Jiang, S.Q.; Yang, L.; et al. Dietary curcumin enhances intestinal antioxidant capacity in ducklings via altering gene expression of antioxidant and key detoxification enzymes. Poult. Sci. 2019, 98, 3705-3714. [CrossRef] [PubMed]

45. Wei, Q.Y.; Chen, W.F.; Zhou, B.; Yang, L.; Liu, Z.L. Inhibition of lipid peroxidation and protein oxidation in rat liver mitochondria by curcumin and its analogues. Biochim. Biophys. Acta 2006, 1760, 70-77. [CrossRef]

46. El-Bahr, S.M. Effect of Curcumin on Hepatic Antioxidant Enzymes Activities and Gene Expressions in Rats Intoxicated with Aflatoxin B1. Phytother. Res. 2015, 29, 134-140. [CrossRef] [PubMed]

47. Hayes, J.D.; Dinkova-Kostova, A.T. The nrf2 regulatory network provides an interface between redox and intermediary metabolism. Trends Biochem. Sci. 2014, 39, 199-218. [CrossRef] [PubMed]

48. Jin, S.J.; Pang, Q.; Yang, H.; Diao, X.P.; Shan, A.S.; Feng, X.J. Effects of dietary resveratrol supplementation on the chemical composition, oxidative stability and meat quality of ducks (Anas platyrhynchos). Food Chem. 2021, 130263. [CrossRef] [PubMed]

49. Martínez-Guzmán, C.; Cortés-Reynosa, P.; Pérez-Salazar, E.; Murillo-González, F.E.; Elizondo, G. Activation of the aryl hydrocarbon receptor (ahr) induces human glutathione s transferase alpha 1 (hgsta1) expression. Chem. Biol. Interact. 2020, $331,109284$. [CrossRef] [PubMed]

50. Rubiolo, J.A.; Mithieux, G.; Vega, F.V. Resveratrol protects primary rat hepatocytes against oxidative stress damage: Activation of the nrf2 transcription factor and augmented activities of antioxidant enzymes. Eur. J. Pharmacol. 2008, 591, 66-72. [CrossRef]

51. Abdel-Wahhab, M.A.; Aly, S.E. Antioxidants and radical scavenging properties of vegetable extracts in rats fed aflatoxincontaminated diet. J. Agric. Food Chem. 2003, 51, 2409-2414. [CrossRef] 
52. Shen, H.M.; Shi, C.Y.; Lee, H.P.; Ong, C.N. Aflatoxin b1-induced lipid peroxidation in rat liver. Toxicol. Appl. Pharmacol. 1994, 127, 145-150. [CrossRef]

53. Wang, H.; Muhammad, I.; Li, W.; Sun, X.; Cheng, P.; Zhang, X. Sensitivity of Arbor Acres broilers and chemoprevention of aflatoxin B1-induced liver injury by curcumin, a natural potent inducer of phase-II enzymes and Nrf2. Environ. Toxicol. Pharmacol. 2018, 59, 94-104. [CrossRef] [PubMed]

54. Liu, Z.; Wang, P.; Shanshan, L.; Guo, R.; Yang, Z. Liquiritin, a novel inhibitor of TRPV1 and TRPA1, protects against LPS-induced acute lung injury. Cell Calcium 2020, 88, 102198. [CrossRef]

55. Shanmugam, N.; Reddy, M.A.; Guha, M.; Natarajan, R. High glucose-induced expression of proinflammatory cytokine and chemokine genes in monocytic cells. Diabetes 2003, 52, 1256-1264. [CrossRef] [PubMed]

56. Ko, H.K.; Lin, A.H.; Perng, D.W.; Lee, T.S.; Kou, Y.R. Lung epithelial trpa1 mediates lipopolysaccharide-induced lung inflammation in bronchial epithelial cells and mice. Front. Physiol. 2020, 11, 596314. [CrossRef] [PubMed]

57. Hou, L.; Gan, F.; Zhou, X.; Zhou, Y.; Qian, G.; Liu, Z.; Huang, K. Immunotoxicity of ochratoxin A and aflatoxin B1 in combination is associated with the nuclear factor kappa B signaling pathway in 3D4/21 cells. Chemosphere 2018, 199, 718-727. [CrossRef]

58. Lang, V.; Rodríguez, M.S. Innate link between nf-kappab activity and ubiquitin-like modifiers. Biochem. Soc. Trans. 2008, 36, 853. [CrossRef] [PubMed]

59. Kumara, S.S.; Gayathri, D.; Hariprasad, P.; Venkateswaran, G.; Swamy, C.T. In vivo AFB1 detoxification by lactobacillus fermentum LC5/a with chlorophyll and immunopotentiating activity in albino mice. Toxicon 2020, 187, 214-222. [CrossRef]

60. Taranu, I.; Hermenean, A.; Bulgaru, C.; Pistol, G.C.; Ciceu, A.; Grosu, I.A.; Marin, D.E. Diet containing grape seed meal by-product counteracts AFB1 toxicity in liver of pig after weaning. Ecotoxicol. Environ. Saf. 2020, 203, 110899. [CrossRef] [PubMed]

61. Liu, Q.; Zhang, D.; Hu, D.; Zhou, X.; Zhou, Y. The role of mitochondria in NLRP3 inflammasome activation. Mol. Immunol. 2018, 103, 115-124. [CrossRef] 